\title{
Learning from South Korea's development experience: Report on the UNRISD-KOICA methodology workshop for the project "Making Development Cooperation Effective" leading to the HLF-4 in Busan
}

\author{
Olive Cocoman, Research Analyst, \\ United Nations Research Institute for Social Development
}

\section{Introduction}

Research ongoing by the United Nations Research Institute for Social Development (UNRISD) and Korea International Cooperation Agency (KOICA) titled 'Making International Development Cooperation Effective' started with the assumption that careful reading of the experience of South Korea is definitely rewarding to those with an interest in making aid effective for development.

Firstly, the analysis of the South Korean case offers experience of the utilization of aid for simultaneous economic growth and poverty reduction from the perspective of the recipient countries, which is very often overshadowed by the donor actions in aid effectiveness. Critical assessment of the development experience of the Republic of Korea from acomprehensive perspective, encompassing political, social and economic dimensions, rather than economic growth alone, is required to understand the recipient states responses to and action for economic growth with poverty reduction. As such, aid and non-aid policies must be considered.

Secondly, the experiences of South Korea, in transition from conflict to post-conflict and nation-building with aid reception and transition from authoritarian to democratic regimes, may provide us with a variety of dynamics between various stakeholders. In these ways, the Koreaexperience can be highlighted to provide relevant insights and policy lessons to 
developing countries facing the challenges and opportunities of the developmental context of the twenty-first century.

Acknowledging that there is no one-size-fits-all model, the current research considers the questions:

1. What lessons can we draw from the Korean experience of success in economic, social and political development which will be valuable for developing countries today?

2. What are the critical issues and questions in interpreting Korean success? How should we interpret Korean developmental success and formulate lessons that can be transferable to developing countries?

At the commencement of the research activity, the research team gathered in Seoul, in May 2011, and over two days presented ideas and brainstormed on the questions. This paper provides a synopsis of points made during the discussion. The overall consensus the participants shared during the workshop is that economic and social policy should not be separated in understanding the development of Koreaand other developing countries, and the Korean experience is a good exemplary case to show the significance of multiple roles of social policy in development. This workshop report highlights the major issues and key points raised during the project workshop.

The list of participants included:

Dr. Kim, Director of Research, Ms You-ah Chung, Director of ODA Research, Ms Hyunjoo Rhee and Dr. Bongkyoon Seo (Policy researchers)

UNRISD: Dr. Ilcheong Yi and Ms Olive Cocoman

Collaborators:

Dr Alice Amsden, MIT by video link

Dr Peter Evans, UC Berkeley by video link

Dr Thandika Mkandawire, LSE

Dr Mike Douglass, University of Hawaii

Dr Mookwon Chung, Yonsei University

Dr Eun Mee Kim, Ewha Women's University

Dr Jae Jing Yang, Yonsei University

Dr Jooha Lee, Dongguk University 
Dr Taekyoon Kim Ewha Women's University

Dr Manohar Pawar, Charles Sturt University

Dr Taewook Huh, University of Bristol

Dr Jinock Lee, Seongkonghoe University

Discussants

Dr Liling Huang, Taiwan National University

Mr. Songyun Park, KOEXIM Bank

Mr. Anselmo Sunghoon Lee, GCAP Korea

Ms. Oh Eun Jung, KOICA Gender Specialist

\section{Human capability enhancement in the capability enhancing Korean state}

The centrality of the state's role in capability expansion has been considered a significant aspect of the South Korean development success. Human capabilities are both a means and ends to development according to Amartya Sen (1995). Theories in development economics support this understanding. The 'institutional turn', (Hoff and Stiglitz 2001, Rodrik et al 2004) posited that growth depends on the design of appropriate and socially-embedded institutional arrangements such as how land reform andincreased productivity among small farmers was an important contribution to equitable growth in South Korea, Taiwan (Hart, 2002), and Colombia and Costa Rica in contrast to Guatemala and El Salvador (Nugent and Robinson, 2010]. In addition, 'new growth theory' (Lucas 1988, Romer 1994 and Helpman 2004) supports the proposition that growth depends primarily on human capital and ideas to support the service sector.

Combining these theories, Peter Evans has purported that a 21st century developmental state must be a 'capability enhancing state'. Expanding the capabilities of the citizenry is not just a welfare goal, 'it is the inescapable foundation of sustained growth in overall GDP' (Evans, 2010:37-38). Speaking through video conference call to the participants in Seoul, Evan's considered that capability enhancing developmental state is the only option of a coherent analytical alternative paradigm of development. Current policy debates on development have gone backwards in the north (UK and US). A more effective paradigm may emerge, which is more credible to come from the global south or later industrialisers and Korea is an excellent candidate for this alternative paradigm. For Evan's being capability enhancing is seen as the central role in the developmental state for which Korea is often 
posited as the prime example. The developmental state, characterized by strong state intervention, as well as extensive regulation and planning is seen in contrast to the regulatory state which intervenes less and empowers regulatory agencies to enforce a variety of standards of behaviour to protect the public. In particular, and as explicit in the Korean context, the developmental state intervenes directly in the economy through a variety of means to promote the growth of new industries and taking the drivers seat in industrialisation policy and related policy domains. Eunmee Kim highlighted that prior to the theorisation of the developmental state, previous theories failed to explain the South Korean model of success. For example, modernisation theory failed to explain East Asiaand resulted in a focus on cultural traits such as Confucianism that generate a passion for education and learning that support productivity growth. Likewise, dependency theory failed to explain countries dependent on foreign capital and technology and development, but without a bad relationship in dependency (Deyo).

Successful state action requires close links to society that Evans calls "embedded autonomy." In South Korea, the focus on institutions as key to development became examples for theory building (Johnson, Amsden, Kim, Lim 1987 and Woo 1989). In particular, the developmental alliance between government and business in the development experience and transformation into a development model is seen as central and will be analysed in this study by Eun Mee Kim. In particular, the states relationship with labour under both authoritarian and democratic regimes is in focus. Between the periods 1972 and 1994, large volumes of funding available to South Korea were used to finance the state-business alliance, key to development (Kim, 1997 27-94). With the use of aid resources and the local capital and commitment of the Chaebol, the South Korean government drove industrialisation.

In the process of human capability expansion, Eun Mee Kim posited that there is a need to show in revision how labour was co-opted in the Korean development experience. She emphasised that the argument of the developmental state as a benevolent benefactor would be gravely wrong, because in the Korean case the suppression of labour was a major reason for the success in Korea. Labour was a subjugated group that it was not able to express any voice. example, an ethnographic study on LG describes the use of secret police to discipline the businesses and workers. In addition, in the large heavy and chemical industry, post-military service workers worked under top-down hierarchical command. Similarly, Jae Jing Yang noted that during the period of rapid economic progress, the 1960s - 1980s, we 
cannot find a productive relationship between government and labour but a relationship with big business. In the trajectory of corporate welfare, increased wages and skills were used to elicit loyalty from trade unions and organised labour. The Chaebol with this cooperation upgraded their status and position in the production line and world economy while price competitiveness demands drove need to decrease labour and increase high technology to control cost of labour.

Similarly, Jae Jing Yang noted that to date we cannot find a productive relationship between government and labour only the state relationship with big business. In the development of corporate welfare, increased wages and skills were used to elicit loyalty from trade unions and organised labour. The Chaebol have within this cooperation upgraded their status and position in the production line while price competitiveness demands have driven the need to decrease labour and increase high technology and control cost of labour.

On the other hand, there is the perspective that the South Korean developmental state was highly attentive to human capability enhancement. Alice Amsden posited that the essential key to drive development is the use Private National Ownership (PNOs), which South Korea can be seen to have built up national industries through policies and practice which focus on national ownership and national skill development, and are the essential keys to drive development. Distinct, in this understanding is that the national investment is outward in focus. Utilising aid, reparation funding from Japan in particular, South Korea invested in outward looking industry. In the past, as the LDC's have been encouraged to have inward FDI for technology development and 'know how' but if we look at South Korea we can see that this most important is for outward foreign direct investments and this has been integrated with nationally owned property. This gives a vertical integration, more stability and less risk, more exposure to new technology and additionally allows for venues to train Korean nationals in roles not normally accessible.

There are a multitude of benefits from this process as elicited by Amsden for the Seoul workshop. Firstly, outward investment has the role of harnessing human capabilities in SMEs. Beginning by building small at the world technological frontier, such investment is crucial because it is impossible to depend on foreign investment to support enough SMEs. When required, first rate outsourcing can be utilised as necessary for producing at lower cost and speed for which Korea has been a model of, while simultaneously building its own national companies. In addition, by engaging in outward investment, new players or emerging economies to move into high technology industry in which growth requires 
investment in research and development. Yet foreign firms, except in China and India, do very little (less than $1 \%$ in South Korea) and fortunately Korean companies have been dedicated to engage is $\mathrm{RnD}$. These activities combine to reverse the brain-drain and moreover, due to the fact that high level jobs required as MNCs promote foreigners only to a certain level, there can be said to exist a race ceiling in addition to the gender ceiling. For example, in the Taiwan joint venture with Phillips, Maurice Chang describes the 'yellow/black/coffee glass ceilings'. The limited opportunity for skills development at CFO, CEO level is overcome Korean companies to support this skill development.

Furthermore, in terms of supported budding industry outward investment has the advantage of allowing the application of local consent on the rules of the WTO as public rules are easy to impose on national industry but not on foreign investment, as shown in examples such as Brazil Petrobral securing Brazilian made oil tankers to carry its oil and Korea's high speed rail project. As such, Amsden's concludes that for the developmental state the essence is nationalistic and is not the universal policies of the enlightenment. It is in its design aiming to secure the whole market, increase national ownership, national assets and national jobs. Amsden challenges Evan's concept of embedded autonomy since she thinks it is not useful today due to the existence of too many companies with increasing capacity to be controlled by the government with a decreasing capacity. In addition, the large MNC in a monopoly engages in the purchasing of local products and as such the issue rests on the state driving performance standards rather than the industries themselves. Towards, these ends, outward FDI and research and development are the most appropriate developmental tools. Thandika Mkandawire proposed that we consider how performance driven by the regulatory statethe strong developmental state is different.

For future research, Thandika Mkandawire highlighted that as Europe now learns from East Asia, innovation frameworks and industrialisation policy are not mentioned and not allowed by WTO but there is the growing acknowledgement that the state matters. As such, being candid about the complexity of the South Korean model is useful in the learning process. Evans set out the future research tasks as follows: To date, we lack comparable detail institutional analysis of the mechanisms of capability expansion by the state by way of analysis of the institutions and structures associated with industrial transformation. There is the need to consider what kind of connections can be built between state and stake-holders to support a capability enhancing state and what networks have accurate information of what is wanted/needed/working or not working? This kind of network was 
built between the state and industry in previous eras. It was not just informational, but also involved political capacity on the part of civil society to ensure state action is in response to collective preferences. Formal institutions are part of this but further networks and deliberative venues are necessary. Also, we need research to consider what makes states efficient and effective in delivery of services, and what are the networks for support and providing the political structures to communicate with state to inform the expansion of services? There are crude measures of capability expansion such as access to education, performance measures on health and how education has improved however we need more detail -an institutional analysis to know how to assist people to live a life they choose to live because strategies based on narrow employment opportunities are not tenable.

\section{Welfarist or Productivist Social Policy?}

Responding to Evan's argument on capability enhancement, Thandika Mkandawire identified gaps in our understanding of social policy that result in the limitation in our ability to be explicit about the capability enhancement capacity of the state. The welfare state is seen an end state to attain and therefore does not contain instruments for developing countries. This can be exemplified by the two large literatures on the developmental states (Amsden etc.) and on welfare regimes in Nordic countries (Esping Andersson etc.) that remain exclusive and researchers are not crossing this conceptual divide. In the interim period, the BLAST model, blood, sweat and tears model before development (Sen) a hard and not a soft side of governance - Korea and Taiwanemphasises the hardness of the state. Yet, the welfare state is highly productive and productive welfare state is a social investment (Myrdal).

Being welfarist and productivist are not separate. For Mkandawire, the embedded autonomy of the state can be seen to exist beyond big business in Korea. This societal embeddedness beyond can be seen though the lens of 'social policy by other means' such as forcing families to undertake social roles. we look back historically, we can identify what is functionally prevalent, for example, land reforms and government subsidise inputs to poor farmers and these must be included in the normal discussion of social policy. Mkandawire will explore the transformative role that social policies working in collaboration and compliment to economic policies that were successful in the Korean development experience.

Relatedly, Mookoon Chung discussed about the instrumental role of social transfers in 
capability expansion. Listing the range of normative social policy tools for which South Korea has examples in public health and education, social security and social transfers, non-contributory pension, child- benefit and school fees as well as direct income subsidies to elderly people (Estevez Abe,2008), the additional utilisation of other social transfers were cited as having had a large role in productivity. For example, subsidised public utility charges for electricity, water, public transportation and telecommunication allowed for prices to be kept low for industry development and simultaneously subsidised urban workers living subsidised urban workers living. Public works and public loans to the disadvantaged were used to provide incomes. In rural areas, agricultural subsidies -fertilisers and purchasing rice by government at a high price and selling at a lower price was another form of subsidy. In addition to this emphasis on the incentives to workers, Chung will consider if the role of social transfers in reducing poverty and increasing inequality is limited or if social policy effects development through consumption and production subsidies to industry.

Noteworthy is the role of the state and the creation of high quality institutions (Evans 1995, Rothstein and Teorell 2008) which rests on the quality of government, to ensure a high administrative capacity and low corruption rate allowing a strong bureaucratic approach to extend coverage.

Delving further into social policies role in strengthen capabilities in times of crisis, Jae Jing Yang's research questions focus on what social policies were employed at the time of crisis to cushion off the time of great economic hardships in Korea. Were there different or similar pattern of social policy responses to economic crisis and what theoretical and policy implications can be drawn from the Korean case in this regard? Yang proposed that particular sources of change and continuity matter. sources of change being the different financial capacity of the state, and the different causes of economic crisis, the regime type and variation in state autonomy and the types of forms of political coalition and the source of continuity being path dependency of policy and a fiscal conservatism deeply entrenched in the Korean economic bureaucracy.

Land reform was evoked during the workshop as a central driver of change in capabilities. Initiated by the US, the reallocation of land resulted in larges increase in agricultural productivity that allowed, over time, the achievement of food security. Mkandawire provoked whether exogenous forces such as revolution are required to allow changes in property rights? Mike Douglass described that in the post-colonial period the normative squeeze on agriculture to fund development in the urban area did not occur in Korea. In the 1950's, land 
reform set equality before industrialization and not after. The 1970's say the commencement of Saemaul Undong which focussed on self-reliant and self-help utilising strong local leadership to develop village infrastructure. For this cause, cement and steel was given to 34, 000 villages. Government supported rural workers by buying rice at higher price from farmers and selling at lower price to city. While Korea did all right in terms of extension services, price support, land reform, there were no urban-rural linkages and the village cannot exist alone.

Specific sectoral efforts are the focus of the remainder of the research. Ilcheong Yi examines education and health policy. Citing example high education and health attainment without high economic growth, such as in Sri Lanka, this research will consider how did the state mobilise and regulate the private sector large role in these sectors. Yi posited that in the early stages of national planning in education and health, strong regulation of private sector, wealth distribution and a functional wealth distribution such as large salaries for teaching staff ensuring these jobs were attractive. Sectoral linkages between education, health and military combined to produce productive linkages which will be explored further. Jooha Lee will additionally examine policy linkages asa key action in governance and consider the direction of economic and social policy such as the impact of economic policy on social protection and vice versa link of social and economic growth.

Gender and the environment are two sectors of state jurisdictions that were marginalized in the course of Korean development success. Jinock Lee, Taewook Huh, and Manohar Pawar all agreed to that learning from failures would be the main task in the research on Korean experience. What happened in gender, rural and environment, what went wrong and why did it go wrong are being analysed. The concerns of the time were different from 21st century concerns, however, it is noteworthy to consider what was won and what was lost in the process of development.

For example, perhaps green growth is not a new issue as every producer has the concern of their own environment. Pawar proposed that there has been no improvement in environmental protection and in 1990's there is increased management has assisted and abated degraded. As such, these mistakes got us here and the question for developing countries rest on if they can leapfrog this situation.

In gender were there more gains than losses resulting from the opportunities for rural female workers to acquire education despite long hours in exploitative work conditions? Oh Eun Jung highlighted that there are still gender issues in South Korea, for example the 
lowest female participation rate in the OCED and the largest wage gap. How do current lasting issues relate to the gender development process in terms of political and economic empowerment? Mkandawire highlighted that many positive outcomes maybe were unintended. For example, in Sweden, gains in gender were not about inequality but were beneficial to equality. Advocacy efforts focussed on achieve the same salary regardless of sector rather than been hung as gender. In the process is looking back retrospectively, can we tease out the deliberate and those that were unintended and form an ex-post discovery as a lesson on the latecomer ex-ante. Jinock Lee will consider why gender inequality is so persistent in Korea, whilst economic development has transformed social relations toward better equality.

\section{The role of aid and foreign civic volunteerism}

Aid funding to South Korea from 1945 to the early 1990's consisted of 12.7 billion USD of grants and loans in addition to reparation funds from Japan. In considering how has foreign assistance mainly in the form of aid affected Korean development in the different phases of development, the nature of foreign assistance to Korea and how the Korean government, business, and civil society responded to aid resources must be understood. Aid effectiveness in the current understanding of the Paris Principles rests on a difficult balance of aspirations that are not played out in practice. Olive Cocoman described tensions between theory and practice for the principles, such how mutual accountability and managing for results jars with genuinely nationally owned development because partnerships in development, as in any domain, are fraught with power issues, in particular, the interests of donors and as a result, the realization of true ownership remains remote. Yi suggested that Korea did achieve successful incorporation of aid resources into the resource pool for national development planning and moreover for sustainable long-term planning. Hyunjoo Rhee noted that key to this success was the importance of good institutions for managing the aid resources which guaranteed ownership and policy space to the Korean government as well as the importance of planning for development that embodied both the Rhee and Park regimes. Thandika Mkandawire cited the importance of understanding this aid-use towards improving the potential of aid today. Towards this end, it is essential to understand the nature of the recipient rather than focus on the donor and what does the multiplicity of donors mean for practice. Also, should aid not fund the big ticket items, such as infrastructure, human capital and industrialization and there is an absorptive capacity 
problem to be addressed. Among these ideas, the use of the resources in Korea as opposed to current practice may have many lessons.

Lastly, the role of civil society is seen a crucial in the capability expansion paradigm whereby embeddedness rest on supporting civil society as a partner to the state. Evans cited Kerala as an example of powerful development of civil society and corresponding improvement in state capacity. Taekyoon Kim described the role of the voluntary sector, in the use international transfers of knowledge and aid for promoting development citing three key successes notable for research; the setting up of local bureaucracies such as KDI and KAVA, the use of voluntary agencies with local populations and the teaching of civic voluntarism. Delving into the experience of Korea may provide new understandings fro civil societies role today. As voluntary associations in Africa can been seen to not be membership organizations but complimentary to the aid establishment according to Thandika Mkandawire, then the capability enhancing role is in need of careful examination.

\section{Conclusion}

This array of ideas and discussion points signal that the final research findings may have much to offer the debate on development assistance in the 21st century. 